\title{
Evaluation of cytotoxic activity and anticancer potential of indigenous Rosemary (Rosmarinus officinalis L.) and Oregano (Origanum vulgare L.) dry extracts on MG-63 bone osteosarcoma human cell line
}

\author{
Cerasela Elena GÎRD ${ }^{1)}$, TeOdora Costea1), Valentina Mitran²) \\ 1) Department of Pharmacognosy, Phytochemistry and Phytotherapy, Faculty of Pharmacy, \\ Carol Davila University of Medicine and Pharmacy, Bucharest, Romania \\ ${ }^{2)}$ Department of Biochemistry and Molecular Biology, University of Bucharest, Romania
}

\begin{abstract}
We aimed to investigate the cytotoxic activity of indigenous Rosemary and Oregano freeze-dried extracts upon MG-63 osteosarcoma human cell line. We have determined the influence of analyzed dry extracts on cell morphology, cell survival and cell proliferation. The evaluation of dry extracts effect upon cell proliferation and viability was assessed by means of 3-[4,5-dimethylthiazol-2-yl]-2,5-diphenyl tetrazolium bromide (MTT) method. For cytotoxicity evaluation, Live \& Dead and lactate dehydrogenase assays have been used. To further investigate the potential anticancer effect, we have studied the influence of dry extracts upon cells, by means of caspase-3/7 assay and proliferation cell nuclear antigen (PCNA) expression. Cells were incubated with extracts in the following concentration range (100-700 $\mu \mathrm{g} / \mathrm{mL})$ for 24 hours. According to our results, both dry extracts have shown cytotoxic effects by means of all used methods. Bone osteosarcoma cells viability significantly decreased with increasing concentration of analyzed extracts (beyond $300 \mu \mathrm{g} / \mathrm{mL}$ for Rosemary dry extract and only at $700 \mu \mathrm{g} / \mathrm{mL}$ for Oregano dry extract). According to our results, apoptosis is one of the main mechanisms involved in the cytotoxic properties of analyzed extracts. Moreover, Rosemary extract has also shown decreased expression of PCNA, when compared to control (untreated cells). Both extracts were standardized in phenolic compounds (being a rich source of flavones and phenolcarboxylic acids), so we assume that these are the main constituents involved in the cytotoxic effect. Still, further preclinical studies are needed to confirm the antitumor properties and to go deeply in the molecular mechanisms involved.
\end{abstract}

Keywords: Rosemary leaves, rosmarinic acid, osteosarcoma, polyphenols, apoptosis.

\section{Introduction}

Cancer is a leading cause of death and an important barrier to increasing life expectancy all over the world. According to the World Health Organization (WHO) for 2019, female breast cancer was the most commonly diagnosed cancer followed by lung, prostate, colorectal and stomach cancers [1]. It is well known that due to metastasis from other malignancies, skeletal bones can host numerous types of cancer, although osteosarcoma, chondrosarcoma and Ewing sarcoma arise in bone itself [2]. Although they account for less than $1 \%$ of diagnosed cancers each year, they are associated with significant mortality $[2,3]$. Among risk factors associated with bone cancers, genetic factors [ $p 53$ oncogene mutation, translocation in chromosomes 11 and 22, retinoblastoma $(R b)$ oncogene alteration], growth factors (tall stature, Paget disease, high birth weight) along with environmental factors (radiation therapy, pollution, orthopedic surgery followed by prosthetic implant) are of great importance $[2,4]$.

Among bone cancers, osteosarcoma is the most common cancer in adolescence, and it is associated with malignant mesenchymal cells. Its peak incidence is in the second decade of life, most prominent between 10-30 years [3].
It usually affects long bones, such as proximal tibia (15\%), distal femur (30\%) and proximal humerus (15\%) [4].

The histological hallmark of osteosarcoma is the development of malignant osteoid, due to proliferation of abnormal osteoblasts, which further leads to suppression of bone marrow, metastasis, and increased pressure in the bone (which represents the main cause of pain, swelling and fracture) [4].

The molecular pathology of osteosarcoma include: (i) alteration of signal transduction pathways [receptor activator of nuclear factor-kappa B ligand (RANKL), Wnt $/ \beta$-catenin, Notch, phosphatidylinositol-3-kinase (PI3K)/ Akt/mammalian target of rapamycin (mTOR), Janus kinase (JAK)/signal transducer and activator of transcription (STAT), bone morphogenetic protein (BMP)], (ii) downstream kinase pathways [integrin-linked kinase, mitogenactivated protein kinase (MAPK) cascades], (iii) alterations in insulin-like growth factor type 1 receptor (IGF-1R) and ErbB2 receptor [5, 6], (iv) altered expression of microribonucleic acid (mi-RNA) (miR-135b, miR-150, miR$542-5 \mathrm{p}$, miR-652) [7], (v) up-regulation of oncogene genes [c-myc, c-Fos, tripartite motif containing 14 (TRIM14)], (vi) epigenetic mechanisms (histone modification or nucleosome remodeling), (vii) inflammation [increased levels of interleukin (IL)-6, IL-17, IL-34, transforming

This is an open-access article distributed under the terms of a Creative Commons Attribution-NonCommercial-ShareAlike 4.0 International Public License, which permits unrestricted use, adaptation, distribution and reproduction in any medium, non-commercially, provided the new creations are licensed under identical terms as the original work and the original work is properly cited. 
growth factor-beta (TGF- $\beta$ ), tumor necrosis factor-alpha (TNF- $\alpha$ )] [8] and increased levels of osteoprotegerin (OPG) [9]. Tumor growth and progression are assisted by growth factors and angiogenic enzymes [vascular endothelial growth factor (VEGF), epidermal growth factor receptor (EGFR), platelet-derived growth factor receptor (PDGF-R)] [10].

Osteosarcoma treatment usually involves surgery and radiation therapy, chemotherapy (with Cisplatin, Doxorubicin, high dose of Methotrexate with Leucovorin rescue and Ifosfamide with or without Etoposide) or immunotherapy [9]. Although chemotherapy has increased overall survival to $60-75 \%$, survival rates have remained the same for the last 20-30 years. Besides, chemotherapy often leads to serious side effects (ototoxicity, nephrotoxicity, or cardiotoxicity) [9]. Moreover, osteosarcoma is characterized by refractoriness to treatment [10-13], since tumors only respond to high doses of chemotherapy and rapidly acquire resistance [2, 9].

Having in mind the previous mentioned aspects, the use of natural compounds, as antitumor agents, for osteosarcoma treatment has become an area of great interest recently, since several reports have demonstrated the beneficial role of bioactive compounds, such as phenolic compounds (curcumin, resveratrol, apigenin, baicalin, etc.), thioderivatives (sulforaphane) or triterpenic compounds (raddeanin) as antitumor agents $[11,14,15]$.

Medicinal plants of the Lamiaceae family are an important source of natural compounds with antibacterial, antiviral, antifungal, antioxidant, sedative, and antitumor effects [16, 17]. Among Lamiaceae species, Rosemary (Rosmarinus officinalis L.) and Oregano (Origanum vulgare L.) are extensively studied due to their complex chemical composition and pharmacological effects. Oregano aerial parts are an important source of essential oil (rich in terpinene-4-ol, $\alpha$-pinene, borneol, thymol, carvacrol, limonene, etc.) [18] and phenolic compounds (gentisic acid, chlorogenic acid, $p$-coumaric acid, rosmarinic acid, quercitrin, rutin, luteolin) [19], with antitumor [20], antioxidant [21], anti-inflammatory [22] and antibacterial properties [21].

Regarding Rosemary, its leaves are an important source of essential oil (rich in 1,8-cineole, camphor, borneol, p-cymene-7-ol, etc.), flavones (hesperidin, diosmin, isoscutellarein 7-O-glucoside, etc.), phenolcarboxylic acids (caffeic acid, chlorogenic acid, rosmarinic acid) and diterpenes (carnosol, carnosic acid, rosmanol) [23]. Rosemary leaves are known for their hepatoprotective, anti-inflammatory, antidiabetic, antimicrobial and neuroprotective effects [23-25].

\section{Aim}

Taking into consideration the scientific literature, the aim of our paper was the evaluation of in vitro cytotoxic activity and potential antitumor effects of indigenous Rosemary and Oregano dry extracts (which were previously characterized in our studies) $[26,27]$ on MG-63 bone osteosarcoma human cell line.

Our purposes were: $(i)$ the evaluation of cell morphology, (ii) cell survival (by means of Live \& Dead assay), (iii) cytotoxicity [lactate dehydrogenase (LDH) assay], (iv) cell proliferation \{3-[4,5-dimethylthiazol-2-yl]-2,5-diphenyl tetrazolium bromide (MTT) assay $\},(v)$ evaluation of proliferating cell nuclear antigen (PCNA) expression, and ( $v i$ ) evaluation of apoptosis by means of caspase-3/7 assay.

\section{Materials and Methods \\ Dry extracts}

Oregano (Origani extractum - OE) and Rosemary (Rosmarini extractum - RE) freeze-dried extracts were obtained using 50\% ethanol as previously described [26, 27]. Both extracts were standardized in phenolic compounds (flavones and phenolcarboxylic acids), by means of spectrophotometric and high-performance liquid chromatography (HPLC) assays [26, 27].

\section{Preparation of samples}

RE and OE dry extracts $(0.0100 \mathrm{~g})$ were dissolved in 10 mL Dulbecco's Modified Eagle's Medium (DMEM) (stock solution). Stock solutions were further used for obtaining the working dilutions $(100 \mu \mathrm{g} / \mathrm{mL}, 300 \mu \mathrm{g} / \mathrm{mL}$, $500 \mu \mathrm{g} / \mathrm{mL}$, and $700 \mu \mathrm{g} / \mathrm{mL}$ ).

\section{Cell line and culture}

MG-63 osteosarcoma human cell line was obtained from American Type Culture Collection (ATCC, Manassas, USA) and maintained in DMEM (Thermo Fisher Scientific, China) supplemented with 10\% Fetal Bovine Serum (FBS) and $1 \%$ Penicillin/Streptomycin, at $37^{\circ} \mathrm{C}$, in a humified atmosphere with $5 \%$ carbon dioxide $\left(\mathrm{CO}_{2}\right)$.

\section{Assessment of cell morphology}

Prior to evaluation of in vitro cytotoxic activity of $\mathrm{OE}$ and RE, we determined the influence of analyzed extracts on MG-63 cell line morphology and density. For this purpose, MG-63 cells were seeded in 24-well plates at an initial density of $1 \times 10^{4}$ cells $/ \mathrm{cm}^{2}$. After 24 hours of culture, the medium was replaced with the appropriate treatments (100-700 $\mu \mathrm{g} / \mathrm{mL} \mathrm{OE} / \mathrm{RE})$ for 24 hours. All experiments were performed against a control that contained untreated cells grown in DMEM. Cell were observed using a Carl Zeiss Axio phase contrast microscope (with AxioCam ERc 5s camera) (Carl Zeiss, Germany).

\section{LDH assay}

LDH assay is a common method used for evaluation of cellular toxicity, since LDH release is considered as an early event of necrosis. LDH is a cytosolic enzyme that leaks out of the cell in case of cell damage. The principle behind the assay is that LDH released into the medium catalyzes the conversion of lactate to pyruvate and converts nicotinamide adenine dinucleotide oxidized form $\left(\mathrm{NAD}^{+}\right)$ into NAD reduced form (NADH). Then, NADH transforms the yellow tetrazolium salt 2-( $p$-iodophenyl)-3-( $p$-nitrophenyl)5 -phenyltetrazolium chloride (INT) into a red formazan. The color change is proportional to the amount of LDH released and was measured at an absorbance of 490-520 nm [28].

LDH assay was performed according to Legrand et al. (1992), using a commercial kit (TOX-7, Sigma-Aldrich, Germany) [29]. Briefly, at the end of the experimental time (after 24 hours incubation of MG-63 cells with OE and RE dry extracts $100-700 \mu \mathrm{g} / \mathrm{mL}$ ), $100 \mu \mathrm{L}$ of culture medium was treated with a mixture of LDH assay substrate, $\mathrm{LDH}$ assay cofactor $\left(\mathrm{NADH}, \mathrm{H}^{+}\right)$and $\mathrm{LDH}$ assay dye 
solution (tetrazolium salt) (prepared according to the commercial kit). The mixture was incubated at room temperature, in the dark, for 30 minutes. The enzymatic reaction was ended by addition of $30 \mu \mathrm{L} 1 \mathrm{~N}$ hydrochloric acid. The absorbance was measured at $\lambda 490 \mathrm{~nm}$ using a Multimode Microplate reader (Thermo Scientific Appliskan).

\section{Assessment of cell survival by means of Live \& Dead assay}

Live \& Dead assay is a quick two-color assay, which is used to determine the viability of cells based on plasma membrane integrity and esterase activity in live cells. The esterase substrate Calcein-AM stains live cells in green, while Ethidium homodimer I (EthD-1) stains dead cells in red (excitation/emission $495 \mathrm{~nm} / 635 \mathrm{~nm}$ ) [30]. The Live \& Dead kit (Invitrogen ${ }^{\mathrm{TM}}$ Molecular Probes ${ }^{\mathrm{TM}}$ ) was used to perform this assay. Briefly, after 24 hours of cell incubation with analyzed dry extracts, the culture medium was removed and the monolayers were washed (three times) with phosphate-buffered saline (PBS) and then stained for 30 minutes at room temperature and darkness, with a fresh solution of Calcein-AM (2 mM) and EthD-1 (4 mM). For highlighting live and dead cells, all samples were analyzed by fluorescence microscopy using an Olympus IX71 fluorescence microscope and Cell F Imaging software for image capture and edit.

\section{Assessment of cell proliferation by means of MTT assay}

The MTT assay is based on the reduction of the tetrazolium salt to its formazan (which is violet colored) only in the mitochondria of living cells, due to mitochondrial dehydrogenases activity [31, 32]. Briefly, after 24 hours of culture, the medium was removed and incubated for three hours with a $1 \mathrm{mg} / \mathrm{mL}$ fresh MTT solution, at $37^{\circ} \mathrm{C}$, allowing cells to form formazan crystals, which were further solubilized in isopropanol. The absorbance was measured at $\lambda 550 \mathrm{~nm}$ using a Multimode microplate reader (Thermo Scientific Appliskan) [31].

\section{PCNA evaluation using Western blot analysis}

Western blot analysis is a widely used analytical technique, which is performed to detect specific proteins, that bind to a certain antibody $[33,34]$. Western blot analysis implies $(i)$ protein extraction and equal loading of proteins, (ii) separation of proteins by molecular weight, (iii) electrophoretic transfer (blotting) and (iv) antibody probing [34]. For our experiment, first we prepared Western blot samples by protein extraction using specialized cell lysis buffers [radioimmunoprecipitation assay (RIPA) or urea/thiourea buffers] and protease/phosphatase inhibitors (P8340 and P2850, Sigma-Aldrich, Germany). Since there must be an equal concentration of proteins per Western blot sample, we conducted a Bradford assay. Briefly, $250 \mu \mathrm{L}$ of Bradford reagent (a mixture of Coomassie Brilliant Blue G-250 and $85 \%$ phosphoric acid) was added to $5 \mu \mathrm{L}$ sample proteins and the change of color was recorded at $\lambda 595 \mathrm{~nm}$ after 60 minutes [enzyme-linked immunosorbent assay (ELISA) Thermo Scientific Appliskan plate reader]. For proteins quantification, we have used a specific calibration curve obtained using Bovine Serum Albumin (BSA) (concentration range $\left.0.1-1.4 \mathrm{mg} / \mathrm{mL}, n=5, R^{2}>0.999\right)$. The separation of proteins by molecular weight was performed using a sodium dodecyl sulfate-polyacrylamide gel electrophoresis (SDSPAGE), using two different sized sieves (a stacking gel and a resolving gel). The cells lysis was mixed with Laemmli discontinuous buffer system (in a ratio of 5:1) and $30 \mu \mathrm{L}$ of this mixture was bought to the electrophoresis gel. The electrophoretic migration was performed at $140 \mathrm{~mA}$. Afterwards, blotting consisted in the electrophoretic transfer of gel contents (by means of Mini Trans-Blot, Bio-Rad Laboratories) on a suitable nitrocellulose membrane (GE Healthcare Life Sciences), using a transfer sandwich with a modified electrode buffer (Towbin buffer - $25 \mathrm{mM}$ Tris; 192 mM Glycine; 20\% methanol; $\mathrm{pH}$ 8.3). The transfer was performed at $160 \mathrm{~mA}$, for two hours. The transfer was verified by membrane Ponceau Red staining protocol for five minutes. Prior to antibody probing, membranes were incubated with a blocking buffer (which included BSA) for one hour. The nitrocellulose membranes were processed using a Western breeze kit; the incubation was performed first with the primary antibody, then the secondary antibody coupled with alkaline phosphatase was added. For chromogenic detection, we have used an alkaline phosphatase detection kit [which included 5-bromo4-chloro-3-indolyl phosphate (BCIP) and nitrotetrazolium blue chloride (NBT)] (Sigma-Aldrich, Germany).

\section{Assessment of apoptosis by means of caspase- $3 / 7$ assay}

The induction of apoptosis was evaluated by means of the caspase-3/7 assay using a CellEvent ${ }^{\mathrm{TM}}$ caspase-3/7 Green detection reagent (Invitrogen C10423). This reagent is a fluorogenic substrate for activated caspase- $3 / 7$ with absorption/emission maxima of 502-503 $\mathrm{nm}$. The reagent consists of a four amino acid peptide (DEVD), which is conjugated to a nucleic acid binding dye. The conjugated dye is non-fluorescent until cleaved from the peptide and bound to deoxyribonucleic acid (DNA) [35]. Briefly, cells were seeded in 24-well plates at an initial density of $1 \times 10^{4}$ cells $/ \mathrm{cm}^{2}$. After 24 hours, the culture medium was replaced with the appropriate treatments $(100 \mu \mathrm{g} / \mathrm{mL}$, $300 \mu \mathrm{g} / \mathrm{mL}, 500 \mu \mathrm{g} / \mathrm{mL}, 700 \mu \mathrm{g} / \mathrm{mL}$ OE/RE extracts). After 24 hours, cells were washed with PBS and treated with $5 \mu \mathrm{L}$ detection reagent for 30 minutes, at $37^{\circ} \mathrm{C}$. Cells were observed by fluorescence microscopy using an Olympus IX71 fluorescence microscope and Cell F Imaging software for image capture and edit.

\section{Statistical analysis}

All analyses were carried out in triplicate. Results are presented as mean \pm standard deviation (SD) and were statistically analyzed using GraphPad Prism 6 software (GraphPad Prism, USA), using Student's $t$-test. A value of $p<0.05$ was considered the threshold for a statistically significant difference.

\section{ㅁ Results}

\section{Assessment of cell morphology}

Osteosarcoma MG-63 cells, without RE and with OE treatment (Figure 1a) showed a polygonal shape, which is considered as a normal cell growth phenomenon.

Regarding the influence of dry extracts upon MG-63 
cells morphology and density, our results have not shown notable differences between untreated cells and cells treated with $100 \mu \mathrm{g} / \mathrm{mL}$ and $300 \mu \mathrm{g} / \mathrm{mL}$ OE. Osteoblasts still had their typical morphology, polygonal and elongated with lightly morphological changes (Figure 1, b and c). However, when cells were treated with concentrations of $500 \mu \mathrm{g} / \mathrm{mL}$ and $700 \mu \mathrm{g} / \mathrm{mL}$ OE, obvious morphological changes were observed. The cells rounded up and showed reduction in number and numerous vacuoles (Figure 1, $\mathrm{d}$ and e).

Regarding cells treated with RE, for $300 \mu \mathrm{g} / \mathrm{mL}$,
$500 \mu \mathrm{g} / \mathrm{mL}$ and $700 \mu \mathrm{g} / \mathrm{mL}$ concentrations, cells became slightly round, with weak interactions between cells (compared to the control - Figure 1a), probably due to cell death (Figure 2, a-c).

The changes that we have observed when treating osteosarcoma cells with $\mathrm{OE}$ (for $500 \mu \mathrm{g} / \mathrm{mL}$ and $700 \mu \mathrm{g} / \mathrm{mL}$ concentrations) and RE (for $300 \mu \mathrm{g} / \mathrm{mL}, 500 \mu \mathrm{g} / \mathrm{mL}$, and $700 \mu \mathrm{g} / \mathrm{mL}$ concentrations) are typically seen in apoptosis, so we assume that analyzed dry extracts had induced apoptotic cell death.
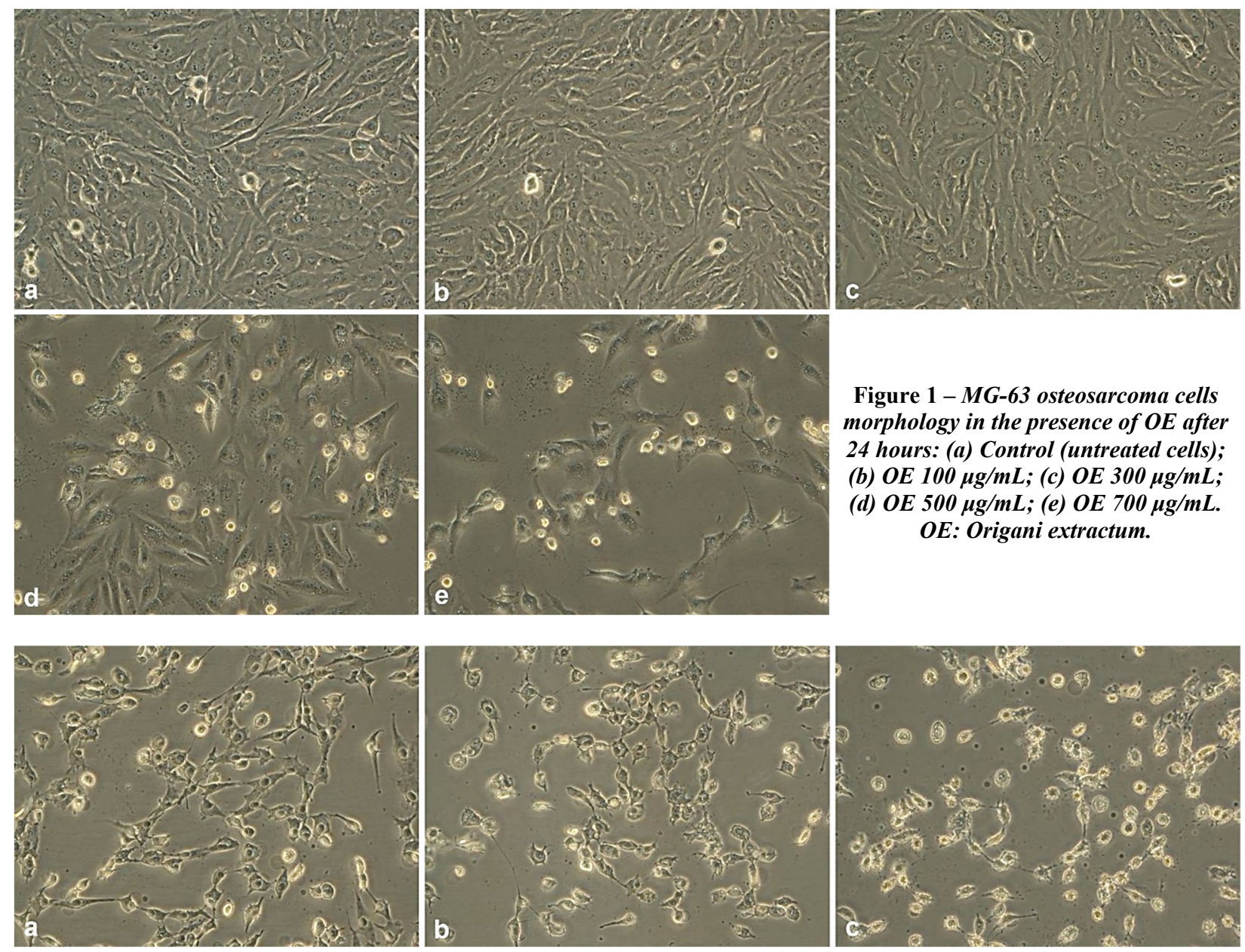

Figure 2-MG-63 osteosarcoma cells morphology in the presence of RE after 24 hours: (a) RE $300 \mu \mathrm{g} / \mathrm{mL}$; (b) RE $500 \mu \mathrm{g} / \mathrm{mL}$; (c) $R E 700 \mu \mathrm{g} / \mathrm{mL}$. RE: Rosmarini extractum.

\section{LDH assay}

To better characterize the effect of RE and OE, bone osteosarcoma cells were subjected to LDH cytotoxicity assay. LDH enzyme leakage from the cytosol of damaged cells into the medium, accompanied by an increase in absorbance is known to be an indicator of cell death, due to membrane damage.

Treatment of osteosarcoma cells with analyzed dry extracts showed a dose dependently increase in LDH release. As seen in Figure 3a, after 24-hour treatment of MG-63 cancer cells with $700 \mu \mathrm{g} / \mathrm{mL} \mathrm{OE}$, we have found a significant release $(* * p<0.01)$ of $\mathrm{LDH}$ in the culture medium compared to the control. However, for the other OE concentrations $(100 \mu \mathrm{g} / \mathrm{mL}, 300 \mu \mathrm{g} / \mathrm{mL}$, and $500 \mu \mathrm{g} / \mathrm{mL})$ we have not found significant differences compared to untreated cells.

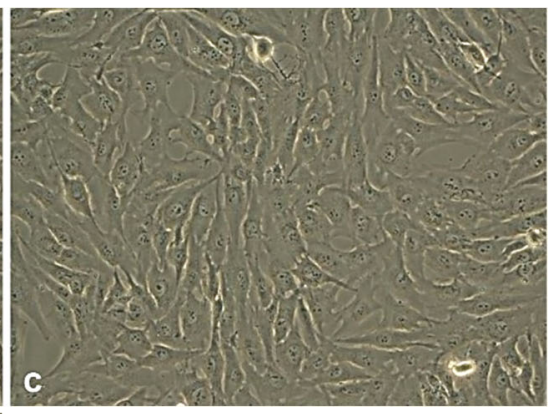

Figure 1 -MG-63 osteosarcoma cells morphology in the presence of $O E$ after 24 hours: (a) Control (untreated cells); (b) $O E 100 \mu \mathrm{g} / \mathrm{mL}$; (c) $O E 300 \mu \mathrm{g} / \mathrm{mL}$; (d) $O E 500 \mu \mathrm{g} / \mathrm{mL}$; (e) $O E 700 \mu \mathrm{g} / \mathrm{mL}$. $O E$ : Origani extractum.
When osteosarcoma cells were treated with RE, a significant LDH release $(* * * p<0.001)$ into the medium (compared to the control) was observed for concentrations beyond $300 \mu \mathrm{g} / \mathrm{mL}$ (Figure $3 \mathrm{~b}$ ).

\section{Assessment of cell survival by means of Live \& Dead assay}

Microscopic observations performed using CalceinAM and EthD-1 confirmed the cytotoxic effects of analyzed dry extracts at different concentrations. In bone osteosarcoma untreated cells, with active esterases, there is a visible strong cytosolic green fluorescence of Calcein (Figures $4 \mathrm{a}$ and $5 \mathrm{a}$ ).

Our results have shown that cells viability treated with $\mathrm{OE}$ and RE dry extracts is dose dependent. As seen in Figure 4, we have not found a significant cytotoxic effect 
when cells were treated with $\mathrm{OE}$ at concentrations of $100 \mu \mathrm{g} / \mathrm{mL}, 300 \mu \mathrm{g} / \mathrm{mL}$, and $500 \mu \mathrm{g} / \mathrm{mL}$ (Figure 4, b-d). However, cells incubated for 24 hours with $\mathrm{OE}$ at $700 \mu \mathrm{g} / \mathrm{mL}$ concentration, had lower cytoplasmatic esterase activity, thus the decreased green fluorescence of Calcein was observed and early apoptotic cells appeared as red in color in the image (Figure 4e).

When cells were incubated with RE dry extract, a significant decrease in green fluorescence of Calcein was observed at concentrations beyond $300 \mu \mathrm{g} / \mathrm{mL}$ (Figure 5 , c-e), which agrees with our previous results (LDH assay).

For both analyzed extracts, apoptotic cells displayed specific features such as cell shrinkage and nuclear condensation.

\section{Assessment of cell proliferation (MTT assay)}

The MTT assay was performed to determine the antiproliferative effects of OE and RE dry extracts upon MG-63 bone osteosarcoma cell line. As shown in Figure 6a, the results of the MTT assay revealed that osteosarcoma cells are sensitive to $\mathrm{OE}$ and the effect was significant at $500 \mu \mathrm{g} / \mathrm{mL}$ $(* * p<0.01)$ and $700 \mu \mathrm{g} / \mathrm{mL}(* * * p<0.001)$ concentrations, as compared to the control group.

Regarding our MTT results, these are correlated with the Live \& Dead assay, since after 24 hours incubation of cells with RE dry extract, a significant decrease in cells viability was observed for MG-63 cells treated with high concentrations (300-700 $\mu \mathrm{g} / \mathrm{mL}$ ) of the extract (Figure $6 \mathrm{~b}$ ).

\section{PCNA assay (Western blotting)}

To examine the molecular mechanisms and underlying changes in cell cycle patterns, we investigated the effects of analyzed dry extracts upon the expression of PCNA in MG-63 osteosarcoma cell line.

As shown in Figure 7, PCNA expression for osteoblasts treated with OE dry extract at all analyzed concentrations, was similar to that of untreated cells. Nevertheless, our results regarding cells treated with RE dry extract (for $500 \mu \mathrm{g} / \mathrm{mL}$ and $700 \mu \mathrm{g} / \mathrm{mL}$ concentrations) have shown a significant reduction of PCNA expression, most likely due to perturbation of cell cycle (Figure 7).

\section{Assessment of apoptosis by means of caspase- $3 / 7$ assay}

Regarding the influence of analyzed dry extracts upon caspase-3/7 activation, we have noticed a dose-dependent effect, starting at $300 \mu \mathrm{g} / \mathrm{mL}$ concentration for both extracts (Figure 8, a-d; Figure 9, a-d), although the activation was much pronounced for osteoblasts treated with RE (Figure 9, a-d).
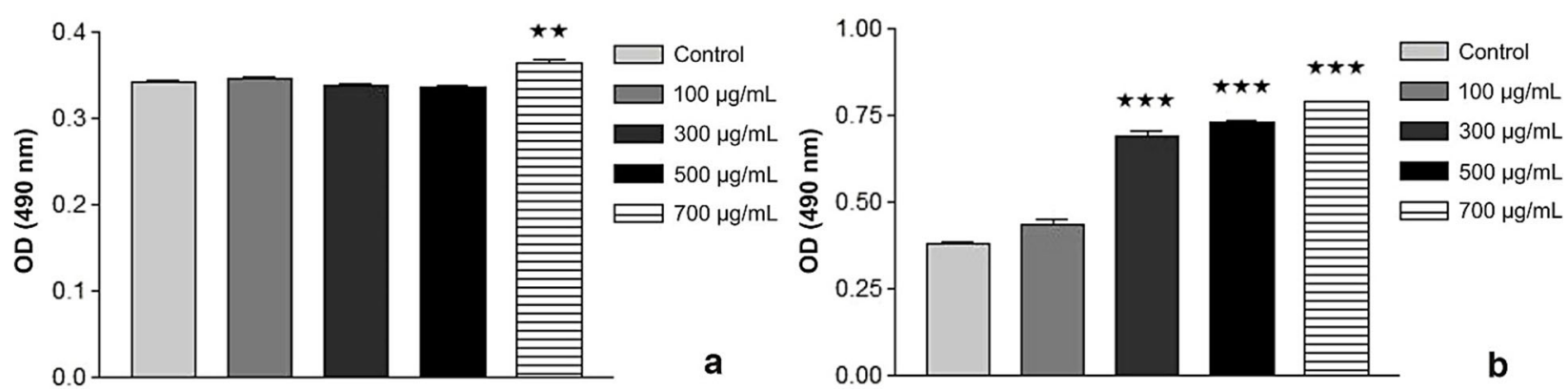

Figure 3 - Evaluation of dry extracts cytotoxicity by means of LDH assay: (a) $O E$; (b) RE. Results are mean $\pm S D$ ( $n=3)$ : $* * p<0.01 ; * * * p<0.001$ (significant differences compared to control). LDH: Lactate dehydrogenase; OD: Optical density; OE: Origani extractum; RE: Rosmarini extractum; SD: Standard deviation.

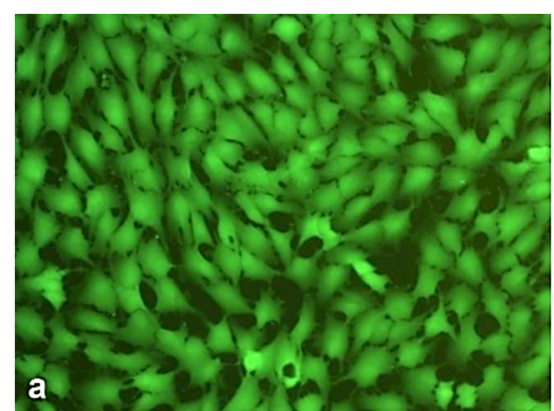

Figure 4 - Fluorescence micrographs of MG-63 cells after 24 hours treatment with $\mathrm{OE}$ at different concentrations (Live \& Dead assay): (a) Control (untreated cells); (b) $O E 100 \mu \mathrm{g} / \mathrm{mL}$; (c) $O E 300 \mu \mathrm{g} / \mathrm{mL}$; (d) $O E 500 \mu \mathrm{g} / \mathrm{mL}$; (e) $O E 700 \mu g / m L$. OE: Origani extractum.
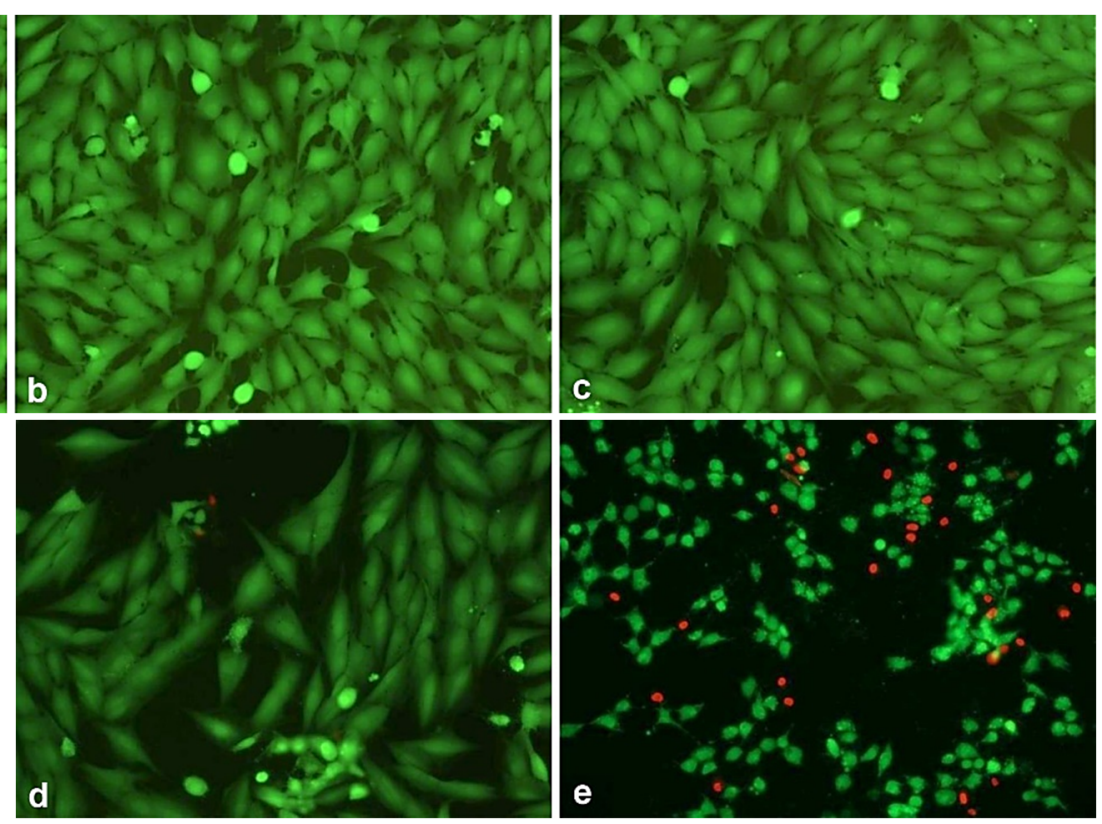

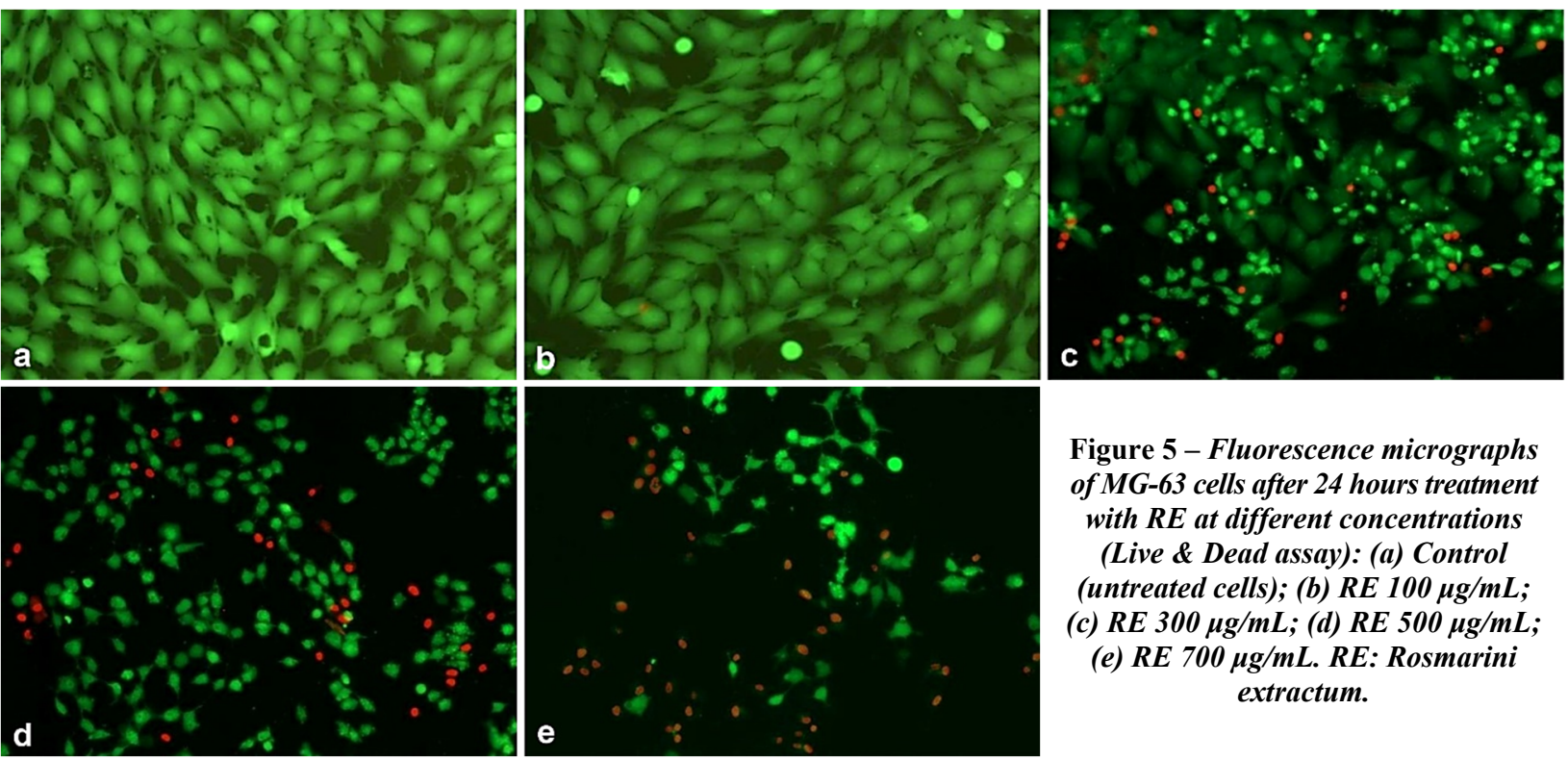

Figure 5 - Fluorescence micrographs of MG-63 cells after 24 hours treatment with $R E$ at different concentrations

(Live \& Dead assay): (a) Control (untreated cells); (b) $R E 100 \mu \mathrm{g} / \mathrm{mL}$; (c) $R E 300 \mu \mathrm{g} / \mathrm{mL}$; (d) $R E 500 \mu \mathrm{g} / \mathrm{mL}$; (e) $R E 700 \mu g / m L$. RE: Rosmarini extractum.
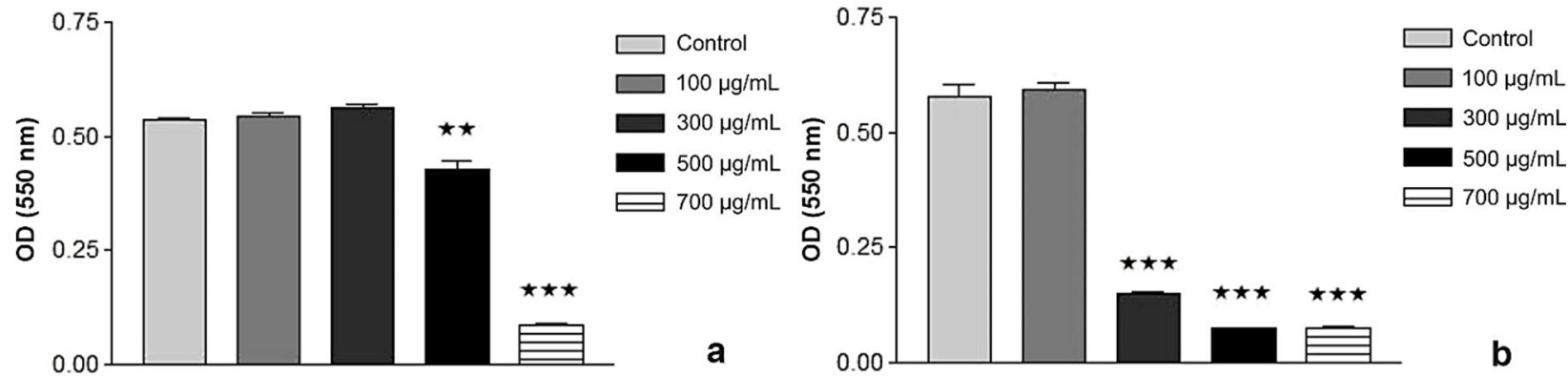

Figure 6 - Results of MTT assay after 24 hours incubation with MG-63 cells: (a) OE; (b) RE. Results are mean $\pm S D$ $(n=3): * * p<0.01 ; * * * p<0.001$ (significant differences compared to control). MTT: 3-[4,5-Dimethylthiazol-2-yl]-2,5diphenyl tetrazolium bromide; OD: Optical density; OE: Origani extractum; RE: Rosmarini extractum; SD: Standard deviation.

Figure 7 - PCNA expression for MG-63 cells treated with $O E$ and RE dry extracts. MM: Molecular mass marker; $\mathrm{OE}$ : Origani extractum; PCNA: Proliferating cell nuclear antigen; RE: Rosmarini extractum.
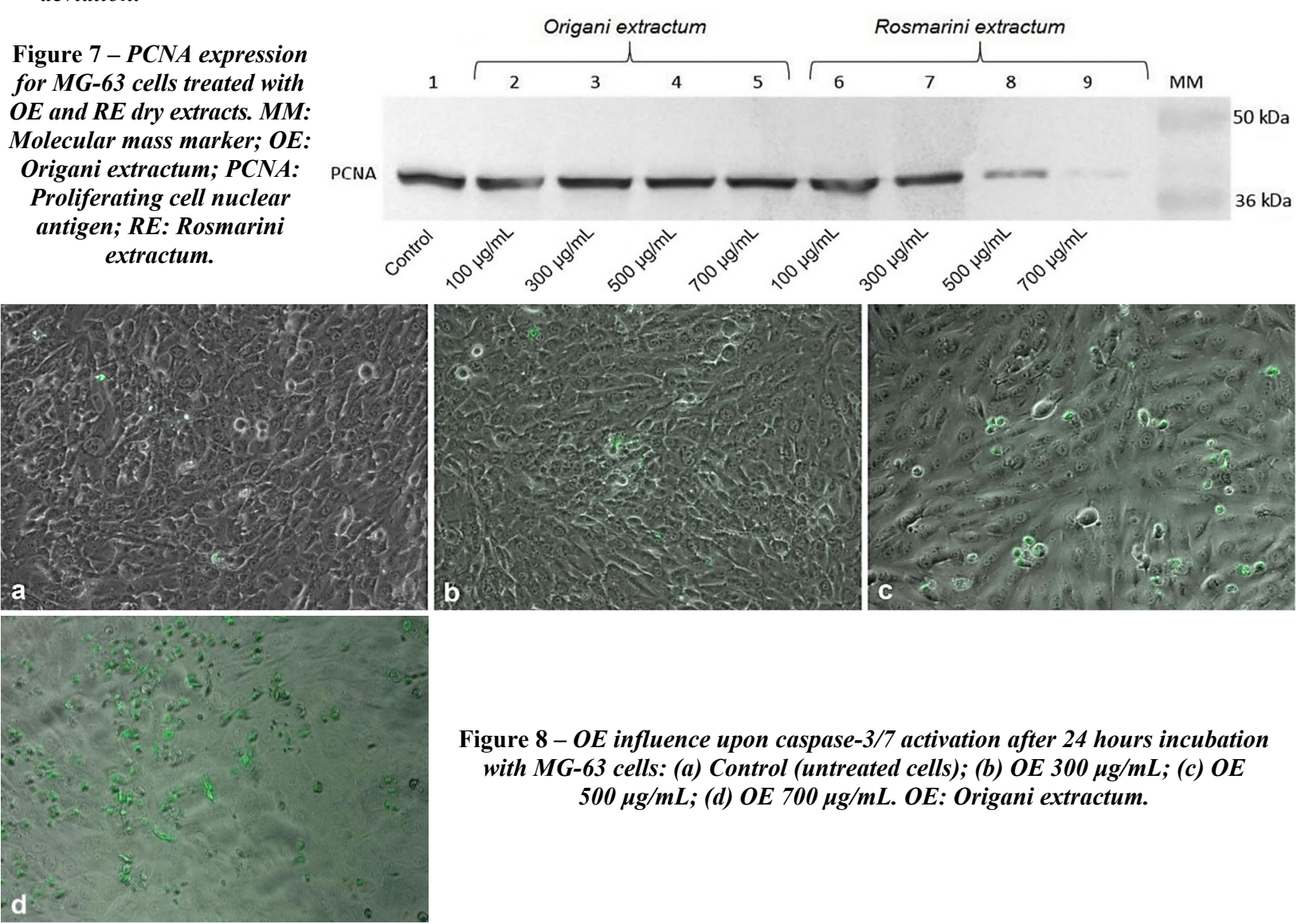

Figure 8 -OE influence upon caspase-3/7 activation after 24 hours incubation with MG-63 cells: (a) Control (untreated cells); (b) $O E 300 \mu \mathrm{g} / \mathrm{mL}$; (c) $\mathrm{OE}$ $500 \mu \mathrm{g} / \mathrm{mL}$; (d) OE $700 \mu \mathrm{g} / \mathrm{mL}$. OE: Origani extractum. 

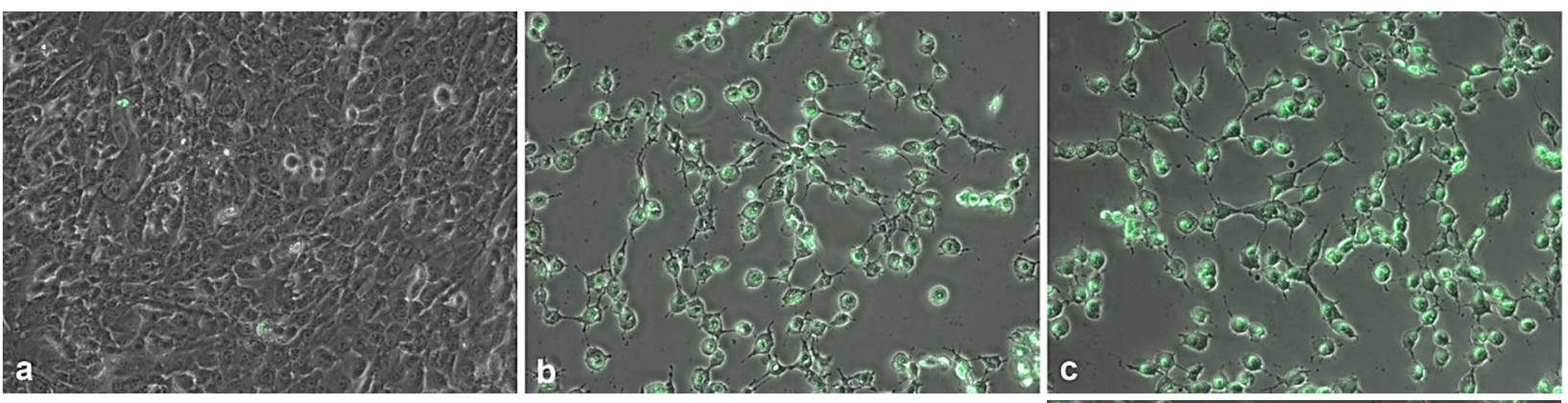

Figure $9-R E$ influence upon caspase-3/7 activation after 24 hours incubation with MG-63 cells: (a) Control (untreated cells); (b) RE $300 \mu \mathrm{g} / \mathrm{mL}$; (c) RE $500 \mu \mathrm{g} / \mathrm{mL}$; (d) RE $700 \mu \mathrm{g} / \mathrm{mL}$. RE: Rosmarini extractum.

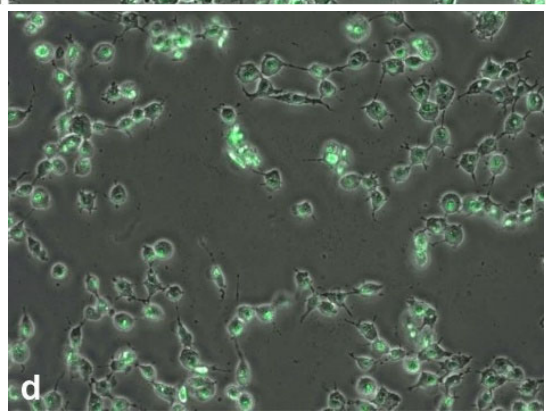

\section{ㅁ Discussions}

Our results have shown cytotoxic effects and promising antitumor potential for both RE and OE on human osteosarcoma MG-63 cell line. The observed effects were dosedependent and much pronounced for RE. According to our previous published results, both extracts are a rich source of phenolic compounds (flavones and phenolcarboxylic acids) [26, 27], so we assume that polyphenols are the main substances involved in the observed cytotoxic effects. OE contains $4.21 \mathrm{~g} \%$ flavones, $52.75 \mathrm{~g} \%$ phenolcarboxylic acids and $27.29 \mathrm{~g} \%$ total phenolic content [27], while RE contains $3.22 \mathrm{~g} \%$ flavones, $34.30 \mathrm{~g} \%$ phenolcarboxylic acids and $31.86 \mathrm{~g} \%$ total polyphenols [26]. By means of HPLC analysis, we have determined the content of rosmarinic acid (5.76 g\% for OE and $3.29 \mathrm{~g} \%$ for RE) [26, 27].

The role of phenolic compounds (flavones, phenolcarboxylic acids, ellagitannins, condensed tannins, curcumin, stilbenes, gingerols, etc.) in cancer prevention and therapy has become an area of great interest recently, since many studies revealed a positive correlation between the consumption of fruits and vegetables (rich in polyphenols) and a decrease in cancer's incidence [36, 37]. Mostly, in vitro and preclinical studies demonstrated that phenolic compounds influence all cancer cell hallmarks (cell morphology, resisting cell death, proliferative signaling, evading growth suppression, replicative immortality and metastasis) [37].

According to our results, both analyzed dry extracts had a significant influence upon osteosarcoma cells morphology (mainly RE at concentrations beyond $300 \mu \mathrm{g} / \mathrm{mL}$ ). It is well known that cell morphology is an important factor of carcinogenesis and metastasis, since cell structure is heterogenous and changes due to different factors (stress, morbid state). Cancer cells usually have a lower stiffness due to disorganization of cytoskeletal structures and rearrangement of the microfilament system [38]. Moreover, according to Sapudom et al., collagen fiber diameter represents a key factor for regulation of cluster formation and invasion. Besides a positive correlation was found between the invasive phenotype of cancer cells (leading to metastasis) and topological/mechanical features of cells
[39]. Regarding osteosarcoma cells, Holenstein et al. have demonstrated a direct relationship between the metastatic potential and in vitro mechanical properties of osteosarcoma cells. Their results have shown a significant decrease in cell contractility and a higher stiffness with increasing metastatic potential [40].

We have obtained promising results regarding the cytotoxic effects of RE and OE upon osteosarcoma cells by means of MTT and LDH assays. MTT assay is a colorimetric method, widely used for evaluation of cell viability and in vitro cytotoxic effects of new drugs or plants/mushroom extracts [41]. Although MTT is one of the most popular assays involved in cell viability evaluation, it has several limitations ( $i$ ) lack of sensitivity (compared to fluorescent methods), (ii) chemical interference (with plant extracts, polyphenols) and (iii) tetrazolium reduction reflects cell metabolism and not cell number [41].

Having in mind these limitations, we continued our research with other assays (LDH, Live \& Dead) to confirm the antitumor potential of RE and OE. It is well known that LDH plays a key role in the Warburg effect and is also linked to tumor growth and invasion. According to previous reports LDHA is highly expressed in tumors while LDHB isoform is usually associated with non-malignant tissues. LDHA is upregulated in many types of cancer (breast and lung carcinomas, pancreatic cancer, oral squamous cell carcinoma) [42]. LDH down-regulation is associated with a decrease in cancer progression and also a reactivation of the mitochondrial function [43]. It is well known that LDH increase in cancer is a consequence of tissue destruction due to neoplastic growth; furthermore, $\mathrm{LDH}$ is a strong predictor of cancer survival among patients with severe types of cancer [43]. Our results are similar to other authors, that found a significant increase of $\mathrm{LDH}$ in osteosarcoma cell lines (MG-63, U2OS). LDH knockdown significantly inhibited migration and metastasis of bone cancer. According to Li et al., LDH represents a prognostic marker for tumor recurrence [43].

Rosmarinic acid is one of the most important phenolic compounds identified and quantified by us in both extracts. Several mechanisms have been proposed for its antitumor 
properties: $(i)$ impaired tumor formation and development; (ii) reduced lipid peroxidation by products; (iii) increased apoptotic protein expression [B-cell lymphoma 2 (BCL-2) protein family]; (iv) cell cycle arrest through modulation of histone deacetylases (HDACs) expression; (v) modulation of different signal pathways or transcription factors involved in carcinogenesis [signal transducer and activator of transcription 3 (STAT3), c-Jun N-terminal kinase (JNK) pathway]; ( $v i)$ reduced TNF- $\alpha$, cyclooxygenase-2 (COX-2) and IL-6/IL-8 levels involved in inflammation; (vii) modulation of p65 expression [44]; (viii) inhibition of certain protein kinases [microtubule affinity-regulating kinase 4 (MARK4)] [45]; (ix) suppression of epithelial to mesenchymal transition (EMT); and $(x)$ up-regulation of miR-506 [46].

We also assume that other phenolic compounds (caffeic acid, chlorogenic acid and ferulic acid), which have been identified by others in Oregano aerial parts and Rosemary leaves $[19,23]$, play a major role in the observed cytotoxic effects. According to previous research, the above-mentioned compounds have shown antiproliferative effects towards breast, liver, and leukemia cells through activation of nuclear factor-kappa $\mathrm{B}(\mathrm{NF}-\kappa \mathrm{B})$ pathway, enhancement of oxidative DNA damage and apoptosis in the presence of other chemotherapeutic agents/radiation or through inhibition of angiogenesis [47]. According to Wang et al., ferulic acid significantly descend osteosarcoma cells viability by promoting apoptosis (through activation of caspase- 3 and apoptosis regulator - Bax proteins), induced cell cycle arrest and down-regulated the expression of cell-cycle related proteins [cyclin-dependent kinase (CDK)2, CDK4 and CDK6] [48]. According to Sapio et al., chlorogenic acid inhibits cell viability, induces cell cycle arrest and apoptosis in different human osteosarcoma cell lines (U2OS, Saos-2 and MG-63) [49].

Several phenolic compounds, mainly flavones, which are found in Oregano and Rosemary aerial parts [19, 23] might also be responsible for the overall cytotoxic effects. Recent research revealed that quercetin induces apoptosis in breast cancer (MCF-7) cells via increase of Bax-2 expression and caspase activation and down-regulation of PI3K/Akt/ mTOR/STAT3 pathway. Moreover, quercetin reduced the phosphorylation of extracellular signal-regulated kinase 1/2 (ERK1/2), which is required for tumor progression and maintenance [50]. Besides, luteolin has shown promising antitumor potential on different cancer cell lines (HepG2, MCF-7) through increased Bax/Bcl-2 ratio, release of reactive oxygen species (ROS) or inhibition of NF- $\kappa$ B pathway [50]. Furthermore, hesperidin exerts antitumor effects by attenuating mitochondrial potential, inducing DNA fragmentation and cytochrome c expression or overexpression of Fas (a death receptor on the surface of cells that leads to programmed cell death) [50].

Our results (MTT, LDH and Live \& Dead assays) revealed a stronger cytotoxic effect for RE, although the flavones and phenolcarboxylic acids contents were lower compared to OE. So, we suppose that other compounds (which were not identified by us), mainly terpenic or volatile constituents are also involved in the overall effects. Carnosol, a diterpenic compound, was found to decrease cell viability of human osteosarcoma MG-63 cell line through induction of ROS production and autophagy [51]. According to Cheng et al., rosmanol, another terpenic compound found in Rosemary leaves, have in vitro cytotoxic effects, on COLO 205 human colorectal adenocarcinoma cells, through promotion of apoptosis (increased expression of caspase-3 and caspase- 9 and overexpression of Fas receptor) [52].

In addition, recent studies have demonstrated that major constituents of Rosemary and Oregano essential oils (carvacrol, 1,8-cineole, camphor or $\alpha$-pinene) have shown cytotoxic effects by various mechanisms [53, 54].

Our results agree with other reports that confirmed the cytotoxic effect of Rosemary leaves extracts on different cancer cell lines [AGS - human gastric carcinoma, KYSE 30 human esophageal squamous cell carcinoma, HT-29-colon adenocarcinoma; (GBM) U87 MG - glioblastoma] [55-57]. Other authors reported cytotoxic activity of $O$. vulgare essential oil and its main constituents (carvacrol, thymol, limonene) on hepatocellular carcinoma cell line (HepG2) [20]. The anticancer activity of different Oregano extracts (ethanolic, hydroalcoholic, aqueous, apolar, etc.) on several cancer cell lines (LoVo - colorectal, CEM - T-cell acute lymphoblastic leukemia, MDA - human breast adenocarcinoma, MCF-7 - breast cell line, A549 - lung cancer, etc.) was also confirmed [58].

To further investigate the possible mechanisms involved in $\mathrm{OE}$ and RE cytotoxicity upon MG-63 cells, we have studied the influence of analyzed extracts upon the PCNA expression and assessment of apoptosis by means of caspase- $3 / 7$ assay.

It is well known that PCNA is a protein that is involved in the metabolism of nucleic acid. PCNA is involved in DNA replication, DNA excision repair, cell cycle control, chromatin assembly and RNA transcription [59]. Its expression is correlated with tumor cell differentiation, tumor size and metastasis [59]. Besides, recent reports have demonstrated that PCNA is overexpressed in a wide range of tumors (gliomas, prostate, breast, or cervical cancer) [59]. Moreover, its concentration fluctuates during the cell cycle, with an increase during G1/S phase and a significant decrease at the beginning of G2 phase and in quiescent cells; the protein is not detected during the M phase. PCNA represents an important cell proliferation marker; increased PCNA expression being involved in cancer progression and poor prognosis [59,60]. Regarding our extracts, a significant reduction in PCNA expression (compared to control cells) was only seen for cells treated with high concentrations of RE dry extract $(500 \mu \mathrm{g} / \mathrm{mL}$ and $700 \mu \mathrm{g} / \mathrm{mL})$. So, we assume that cell cycle arrest (probably induced by rosmarinic acid, chlorogenic acid and ferulic acid) [44, 48 ] is one of the mechanisms involved in RE cytotoxic properties. Instead for OR extract, most likely other mechanisms are involved, probably apoptosis, modulation of different signal pathways or DNA fragmentation [50].

Our results regarding the evaluation of apoptosis by means of caspase-3/7 assay have clearly demonstrated that both extracts induce dose-dependent apoptotic effects. Caspase protease family is a key regulator of apoptosis, which leads to DNA fragmentation, nuclear condensation, and membrane blebbing [36]. The mammalian caspases are divided into three groups according to their role: executioner caspases (caspase-3 and caspase-7), initiator caspases (caspase-2, -8, - 9, -10) and inflammatory caspases (caspase-1, -4, - 5, - 11, - 12) [36]. Caspase-3 and caspase- 7 are of great importance for cancer therapy, 
due to their involvement in cleaving different regulatory proteins that silent the functions of the cell and are involved in apoptosis. In addition to inducing apoptosis, caspase-3 activation is involved in cleaving other substrates [Rat sarcoma (Ras) guanosine triphosphatase (GTP-ase)], which in turn sensitizes tumor cells to apoptosis [36].

Polyphenols are unique molecules which can regulate cell apoptosis, which represents an important aspect in cancer treatment. Several preclinical and clinical studies have shown that phenolic compounds (quercetin, ferulic acid, chlorogenic acid, etc.) are involved in all apoptosis mechanisms: $(i)$ the intrinsic pathway (that starts within the cell and is mediated by Bax proteins, release of cytochrome $\mathrm{c}$ which further activates caspase-3 and caspase-9), (ii) the extrinsic pathway (that involves binding of death ligands to transmembrane death receptors with further caspase- 8 activation), and (iii) the perforingranzyme pathway $[50,61]$.

Although our results regarding the potential antitumor effects of RE and OE are encouraging, another point to be considered is that in vitro studies do not consider the metabolic transformations of phenolic compounds and their physiological concentrations. On the other hand, polyphenols bioavailability is influenced by their chemical structure, interaction with food components, gastrointestinal absorption, first pass metabolism, enterohepatic circulation, or interaction with gut microbiota $[62,63]$. Furthermore, the biological activities of some polyphenols may be also mediated by their metabolites, which are only produced in vivo [64].

\section{무 Conclusions}

Overall, analyzed dry extracts from indigenous Oregano aerial parts and Rosemary leaves have shown cytotoxic effects and promising antitumor potential upon MG-63 human osteosarcoma cell line. The cytotoxic effect was dose dependent. OE has shown cytotoxic effects at the highest concentration $(700 \mu \mathrm{g} / \mathrm{mL})$, while for RE this effect was seen starting with $300 \mu \mathrm{g} / \mathrm{mL}$ concentration. We assume that the observed effects are the consequence of apoptosis (both extracts were involved in caspase-3/7 activation) and decreased expression of PCNA (only for RE dry extract). Further preclinical studies are needed to confirm the antitumor effects and to go deeply in the molecular mechanisms involved.

\section{Conflict of interests}

The authors declare no conflict of interests.

\section{Funding}

This research received no specific grant from any funding agency in the public, commercial, or not-for-profit sector.

\section{References}

[1] Sung H, Ferlay J, Siegel RL, Laversanne M, Soerjomataram I, Jemal A, Bray F. Global Cancer Statistics 2020: GLOBOCAN estimates of incidence and mortality worldwide for 36 cancers in 185 countries. CA Cancer J Clin, 2021, 71(3):209-249. https://doi.org/10.3322/caac.21660 PMID: 33538338

[2] Ferguson JL, Turner SP. Bone cancer: diagnosis and treatment principles. Am Fam Physician, 2018, 98(4):205-213. PMID: 30215968

[3] Misaghi A, Goldin A, Awad M, Kulidjian AA. Osteosarcoma: a comprehensive review. SICOT J, 2018, 4:12. https://doi.org/ 10.1051/sicotj/2017028 PMID: 29629690 PMCID: PMC5890448
[4] Siddiqui S, Singh A, Ali S, Yadav M, Pandey V, Sharma D. Metallothionein: potential therapeutic target for osteosarcoma. J Oncol Sci, 2019, 5(1):13-18. https://doi.org/10.1016/j.jons. 2019.02.002

[5] Adamopoulos C, Gargalionis AN, Piperi C, Papavassiliou AG. Recent advances in mechanobiology of osteosarcoma. J Cell Biochem, 2017, 118(2):232-236. https://doi.org/10.1002/jcb. 25660 PMID: 27463370

[6] Liu Y, Guan J, Chen X. Identification of differentially expressed genes under the regulation of transcription factors in osteosarcoma. Pathol Oncol Res, 2019, 25(3):1091-1102. https:// doi.org/10.1007/s12253-018-0519-0 PMID: 30411296

[7] Sampson VB, Yoo S, Kumar A, Vetter NS, Kolb EA. Micro RNAs and potential targets in osteosarcoma. Front Pediatr, 2015, 3:69. https://doi.org/10.3389/fped.2015.00069 PMID: 26380245 PMCID: PMC4547013

[8] De Azevedo JWV, de Medeiro Fernandes TAA, Fernandes JV Jr, de Azevedo JCV, Lanza DCF, Bezerra CM, Andrade VS, de Araújo JMG, Fernandes JV. Biology and pathogenesis of human osteosarcoma. Oncol Lett, 2020, 19(2):1099-1116. https://doi.org/10.3892/ol.2019.11229 PMID: 31966039 PMCID: PMC6955653

[9] Lindsey BA, Markel JE, Kleinerman ES. Osteosarcoma overview. Rheumatol Ther, 2017, 4(1):25-43. https://doi.org/10.1007/ S40744-016-0050-2 PMID: 27933467 PMCID: PMC5443719

[10] He H, Ni J, Huang J. Molecular mechanisms of chemoresistance in osteosarcoma (review). Oncol Lett, 2014, 7(5):1352-1362. https://doi.org/10.3892/ol.2014.1935 PMID: 24765137 PMCID: PMC3997672

[11] Angulo P, Kaushik G, Subramaniam D, Dandawate P, Neville K, Chastain K, Anant S. Natural compounds targeting major cell signaling pathways: a novel paradigm for osteosarcoma therapy. J Hematol Oncol, 2017, 10(1):10. https://doi.org/10. 1186/s13045-016-0373-Z PMID: 28061797 PMCID: PMC 5219787

[12] Durfee RA, Mohammed M, Luu HH. Review of osteosarcoma and current management. Rheumatol Ther, 2016, 3(2):221243. https://doi.org/10.1007/s40744-016-0046-y PMID: 27761754 PMCID: PMC5127970

[13] Lilienthal I, Herold N. Targeting molecular mechanisms underlying treatment efficacy and resistance in osteosarcoma: a review of current and future strategies. Int J Mol Sci, 2020, 21(18):6885. https://doi.org/10.3390/ijms21186885 PMID: 32961800 PMCID: PMC7555161

[14] Ma B, Zhu J, Zhao A, Zhang J, Wang Y, Zhang H, Zhang L, Zhang Q. Raddeanin A, a natural triterpenoid saponin compound, exerts anticancer effect on human osteosarcoma via the ROS/JNK and NF- $K$ B signal pathway. Toxicol Appl Pharmacol, 2018, 353:87-101. https://doi.org/10.1016/j.taap.2018.05.025 PMID: 29847772

[15] Liu Y, Hong Z, Chen P, Wang J, Zhou Y, Huang J. Baicalin inhibits growth and induces apoptosis of human osteosarcoma cells by suppressing the AKT pathway. Oncol Lett, 2019, 18(3):3188-3194. https://doi.org/10.3892/ol.2019.10617 PMID: 31452795 PMCID: PMC6676451

[16] Cocan I, Alexa E, Danciu C, Radulov I, Galuscan A, Obistioiu D, Morvay AA, Sumalan RM, Poiana MA, Pop G, Dehelean CA. Phytochemical screening and biological activity of Lamiaceae family plant extracts. Exp Ther Med, 2018, 15(2):1863-1870. https://doi.org/10.3892/etm.2017.5640 PMID: 29434776 PMCID: PMC5776630

[17] Mouhid L, Gómez de Cedrón M, Vargas T, García-Carrascosa E, Herranz N, García-Risco M, Reglero G, Fornari T, Ramírez de Molina A. Identification of antitumoral agents against human pancreatic cancer cells from Asteraceae and Lamiaceae plant extracts. BMC Complement Altern Med, 2018, 18(1):254. https://doi.org/10.1186/s12906-018-2322-6 PMID: 30223811 PMCID: PMC6142333

[18] Morshedloo MR, Salami SA, Nazeri V, Maggi F, Craker L. Essential oil profile of oregano (Origanum vulgare L.) populations grown under similar soil and climate conditions. Ind Crops Prod, 2018, 119:183-190. https://doi.org/10.1016/ j.indcrop.2018.03.049

[19] Oniga I, Puşcaş C, Silaghi-Dumitrescu R, Olah NK, Sevastre B, Marica R, Marcus I, Sevastre-Berghian AC, Benedec D, Pop CE, Hanganu D. Origanum vulgare ssp. vulgare: chemical composition and biological studies. Molecules, 2018, 23(8):2077. https://doi.org/10.3390/molecules23082077 PMID: 30126246 PMCID: PMC6222339 
[20] Elshafie HS, Armentano MF, Carmosino M, Bufo SA, De Feo V, Camele I. Cytotoxic activity of Origanum vulgare L. on hepatocellular carcinoma cell line HepG2 and evaluation of its biological activity. Molecules, 2017, 22(9):1435. https://doi.org/10.3390/ molecules22091435 PMID: 28867805 PMCID: PMC6151800

[21] Simirgiotis MJ, Burton D, Parra F, López J, Muñoz $P$, Escobar H, Parra C. Antioxidant and antibacterial capacities of Origanum vulgare L. essential oil from the arid Andean Region of Chile and its chemical characterization by GC-MS. Metabolites, 2020, 10(10):414. https://doi.org/10.3390/metabo 10100414 PMID: 33081116 PMCID: PMC7602849

[22] Sharifi-Rigi A, Heidarian E, Amini SA. Protective and antiinflammatory effects of hydroalcoholic leaf extract of Origanum vulgare on oxidative stress, TNF- $\alpha$ gene expression and liver histological changes in paraquat-induced hepatotoxicity in rats. Arch Physiol Biochem, 2019, 125(1):56-63. https://doi.org/10. 1080/13813455.2018.1437186 PMID: 29425067

[23] Nieto G, Ros G, Castillo J. Antioxidant and antimicrobial properties of rosemary (Rosmarinus officinalis, L.): a review. Medicines (Basel), 2018, 5(3):98. https://doi.org/10.3390/medicines503 0098 PMID: 30181448 PMCID: PMC6165352

[24] Andrade JM, Faustino C, Garcia C, Ladeiras D, Reis CP, Rijo P. Rosmarinus officinalis $\mathrm{L}$.: an update review of its phytochemistry and biological activity. Future Sci OA, 2018, 4(4):FSO283. https://doi.org/10.4155/fsoa-2017-0124 PMID: 29682318 PMCID: PMC5905578

[25] Shinjyo N, Green J. Are sage, rosemary and lemon balm effective interventions in dementia? A narrative review of the clinical evidence. Eur J Integr Med, 2017, 15:83-96. https:// doi.org/10.1016/j.eujim.2017.08.013

[26] Gîrd CE, Nencu I, Popescu ML, Costea T, Duțu LE, Balaci TD, Olaru OT. Chemical, antioxidant and toxicity evaluation of rosemary leaves and its dry extract. Farmacia, 2017, 65(6): 978-983.

[27] Gîrd CE, Duţu LE, Costea T, Nencu I, Popescu ML, Olaru OT. Preliminary research concerning the obtaining of herbal extracts with potential neuroprotective activity. Note I. Obtaining and characterization of a selective Origanum vulgare L. dry extract. Farmacia, 2016, 64(5):680-687.

[28] Parhamifar L, Andersen H, Moghimi SM. Lactate dehydrogenase assay for assessment of polycation cytotoxicity. Methods $\mathrm{Mol}$ Biol, 2013, 948:13-22. https://doi.org/10.1007/978-1-62703140-0 2 PMID: 23070760

[29] Legrand C, Bour JM, Jacob C, Capiaumont J, Martial A, Marc A, Wudtke M, Kretzmer G, Demangel C, Duval D, Hache J. Lactate dehydrogenase (LDH) activity of the cultured eukaryotic cells as marker of the number of dead cells in the medium. J Biotechnol, 1992, 25(3):231-243. https://doi.org/10.1016/ 0168-1656(92)90158-6 PMID: 1368802

[30] Ghali W, Vaudry D, Jouenne T, Marzouki MN. Lycium europaeum fruit extract: antiproliferative activity on A549 human lung carcinoma cells and PC12 rat adrenal medulla cancer cells and assessment of its cytotoxicity on cerebellum granule cells. Nutr Cancer, 2015, 67(4):637-646. https://doi.org/10.1080/ 01635581.2015.1017054 PMID: 25825796

[31] Mosmann T. Rapid colorimetric assay for cellular growth and survival: application to proliferation and cytotoxicity assays. $\mathrm{J}$ Immunol Methods, 1983, 65(1-2):55-63. https://doi.org/10. 1016/0022-1759(83)90303-4 PMID: 6606682

[32] Śliwka L, Wiktorska K, Suchocki P, Milczarek M, Mielczarek S, Lubelska K, Cierpiał T, Łyżwa P, Kiełbasiński P, Jaromin A Flis A, Chilmonczyk Z. The comparison of MTT and CVS assays for the assessment of anticancer agent interactions. PLoS One, 2016, 11(5):e0155772. https://doi.org/10.1371/ journal.pone.0155772 PMID: 27196402 PMCID: PMC4873276

[33] Venturi A, Dal Piaz F, Giovannini C, Gramantieri L, Chieco P, Bolondi L. Human hepatocellular carcinoma expresses specific PCNA isoforms: an in vivo and in vitro evaluation. Lab Invest, 2008, 88(9):995-1007. https://doi.org/10.1038/labinvest.2008. 50 PMID: 18521065

[34] Pillai-Kastoori L, Schutz-Geschwender AR, Harford JA. A systematic approach to quantitative Western blot analysis. Anal Biochem, 2020, 593:113608. https://doi.org/10.1016/j. ab.2020.113608 PMID: 32007473

[35] Alblewi FF, Okasha RM, Eskandrani AA, Afifi TH, Mohamed HM, Halawa AH, Fouda AM, Al-Dies AAM, Mora A, El-Agrody AM. Design and synthesis of novel heterocyclic-based $4 \mathrm{H}$-benzo [h]chromene moieties: targeting antitumor caspase $3 / 7$ activities and cell cycle analysis. Molecules, 2019, 24(6):1060. https:// doi.org/10.3390/molecules24061060 PMID: 30889862 PMCID: PMC6471608

[36] Boice A, Bouchier-Hayes L. Targeting apoptotic caspases in cancer. Biochim Biophys Acta Mol Cell Res, 2020, 1867(6): 118688. https://doi.org/10.1016/j.bbamcr.2020.118688 PMID: 32087180 PMCID: PMC7155770

[37] Estrela JM, Mena S, Obrador E, Benlloch M, Castellano G, Salvador R, Dellinger RW. Polyphenolic phytochemicals in cancer prevention and therapy: bioavailability versus bioefficacy. J Med Chem, 2017, 60(23):9413-9436. https://doi.org/10.1021/ acs.jmedchem.6b01026 PMID: 28654265

[38] Hayashi K, Iwat M. Stiffness of cancer cells measured with an AFM indentation method. J Mech Behav Biomed Mater, 2015, 49:105-111. https://doi.org/10.1016/j.jmbbm.2015.04. 030 PMID: 26004036

[39] Sapudom J, Rubner S, Martin S, Kurth T, Riedel S, Mierke CT, Pompe T. The phenotype of cancer cell invasion controlled by fibril diameter and pore size of 3D collagen networks. Biomaterials, 2015, 52:367-375. https://doi.org/10.1016/j. biomaterials.2015.02.022 PMID: 25818443

[40] Holenstein CN, Horvath A, Schär B, Schoenenberger AD Bollhalder M, Goedecke N, Bartalena G, Otto O, Herbig M, Guck J, Müller DA, Snedeker JG, Silvan U. The relationship between metastatic potential and in vitro mechanical properties of osteosarcoma cells. Mol Biol Cell, 2019, 30(7):887-898. https://doi.org/10.1091/mbc.E18-08-0545 PMID: 30785850 PMCID: PMC6589788

[41] Stepanenko AA, Dmitrenko VV. Pitfalls of the MTT assay: direct and off-target effects of inhibitors can result in over/ underestimation of cell viability. Gene, 2015, 574(2):193-203. https://doi.org/10.1016/j.gene.2015.08.009 PMID: 26260013

[42] Gallo M, Sapio L, Spina A, Naviglio D, Calogero A, Naviglio S. Lactic dehydrogenase and cancer: an overview. Front Biosci (Landmark Ed), 2015, 20:1234-1249. https://doi.org/10.2741/ 4368 PMID: 25961554

[43] Li C, Chen Y, Bai P, Wang J, Liu Z, Wang T, Cai Q. LDHB may be a significant predictor of poor prognosis in osteosarcoma. Am J Transl Res, 2016, 8(11):4831-4843. PMID: 27904684 PMCID: PMC5126326

[44] Nadeem M, Imran M, Aslam Gondal T, Imran A, Shahbaz M, Muhammad Amir R, Wasim Sajid M, Batool Qaisrani T, Atif M, Hussain G, Salehi B, Adrian Ostrander E, Martorell M, Sharifi-Rad J, Cho WC, Martins N. Therapeutic potential of rosmarinic acid: a comprehensive review. Appl Sci, 2019, 9(15):3139. https://doi.org/10.3390/app9153139

[45] Anwar S, Shamsi A, Shahbaaz M, Queen A, Khan P, Hasan GM, Islam A, Alajmi MF, Hussain A, Ahmad F, Hassan Ml. Rosmarinic acid exhibits anticancer effects via MARK4 inhibition. Sci Rep, 2020, 10(1):10300. https://doi.org/10.1038/s41598-020-65648-z PMID: 32587267 PMCID: PMC7316822

[46] Han Y, Ma L, Zhao L, Feng W, Zheng X. Rosmarinic inhibits cell proliferation, invasion and migration via up-regulating miR-506 and suppressing MMP2/16 expression in pancreatic cancer. Biomed Pharmacother, 2019, 115:108878. https:// doi.org/10.1016/j.biopha.2019.108878 PMID: 31060006

[47] Roleira FMF, Tavares-da-Silva EJ, Varela CL, Costa SC, Silva T, Garrido J, Borges F. Plant derived and dietary phenolic antioxidants: anticancer properties. Food Chem, 2015, 183: 235-258. https://doi.org/10.1016/j.foodchem.2015.03.039 PMID: 25863633

[48] Wang T, Gong X, Jiang R, Li H, Du W, Kuang G. Ferulic acid inhibits proliferation and promotes apoptosis via blockage of PI3K/Akt pathway in osteosarcoma cell. Am J Transl Res, 2016, 8(2):968-980. PMID: 27158383 PMCID: PMC 4846940

[49] Sapio L, Salzillo A, Illiano M, Ragone A, Spina A, Chiosi E, Pacifico S, Catauro M, Naviglio S. Chlorogenic acid activates ERK1/2 and inhibits proliferation of osteosarcoma cells. J Cell Physiol, 2020, 235(4):3741-3752. https://doi.org/10.1002/jcp. 29269 PMID: 31602671

[50] Abotaleb M, Samuel SM, Varghese E, Varghese S, Kubatka P, Liskova A, Büsselberg D. Flavonoids in cancer and apoptosis. Cancers, 2019, 11(1):28. https://doi.org/10.3390/cancers110 10028 PMID: 30597838 PMCID: PMC6357032 
[51] Lo YC, Lin YC, Huang YF, Hsieh CP, Wu CC, Chang IL, Chen $\mathrm{CL}$, Cheng $\mathrm{CH}$, Chen HY. Carnosol-induced ROS inhibits cell viability of human osteosarcoma by apoptosis and autophagy. Am J Chin Med, 2017, 45(8):1761-1772. https:// doi.org/10.1142/S0192415X17500951 PMID: 29121803

[52] Cheng AC, Lee MF, Tsai ML, Lai CS, Lee JH, Ho CT, Pan MH. Rosmanol potently induces apoptosis through both the mitochondrial apoptotic pathway and death receptor pathway in human colon adenocarcinoma COLO 205 cells. Food Chem Toxicol, 2011, 49(2):485-493. https://doi.org/10.1016/j.fct.2010. 11.030 PMID: 21112365

[53] Hou J, Zhang Y, Zhu Y, Zhou B, Ren C, Liang S, Guo Y. $\alpha$-Pinene induces apoptotic cell death via caspase activation in human ovarian cancer cells. Med Sci Monit, 2019, 25:66316638. https://doi.org/10.12659/MSM.916419 PMID: 31482864 PMCID: PMC6743669

[54] Coccimiglio J, Alipour M, Jiang ZH, Gottardo C, Suntres Z. Antioxidant, antibacterial, and cytotoxic activities of the ethanolic Origanum vulgare extract and its major constituents. Oxid Med Cell Longev, 2016, 2016:1404505. https://doi.org/10.1155/ 2016/1404505 PMID: 27051475 PMCID: PMC4804097

[55] Karimi N, Rashedi J, Mahdavi Poor B, Arabi S, Ghorbani M, Tahmasebpour N, Asgharzadeh M. Cytotoxic effect of rosemary extract on gastric adenocarcinoma (AGS) and esophageal squamous cell carcinoma (KYSE30) cell lines. Gastroenterol Hepatol Bed Bench, 2017, 10(2):102-107. PMID: 28702133 PMCID: PMC5495896

[56] Borrás-Linares I, Pérez-Sánchez A, Lozano-Sánchez J, Barrajón-Catalán E, Arráez-Román D, Cifuentes A, Micol V, Carretero AS. A bioguided identification of the active compounds that contribute to the antiproliferative/cytotoxic effects of rosemary extract on colon cancer cells. Food Chem Toxicol, 2015 80:215-222. https://doi.org/10.1016/j.fct.2015.03.013 PMID: 25801906
[57] Özdemir MD, Göktürk D. The concurrent effect of acyclovir and rosemary on glioblastoma cell culture. Cell Mol Biol (Noisy-le-grand), 2019, 65(3):66-71. https://doi.org/10.14715/ cmb/2019.65.3.9 PMID: 30942157

[58] Pezzani R, Vitalini S, Iriti M. Bioactivities of Origanum vulgare L.: an update. Phytochem Rev, 2017, 16(6):1253-1268. https:// doi.org/10.1007/s11101-017-9535-z

[59] Juríková M, Danihel L', Polák Š, Varga I. Ki67, PCNA, and MCM proteins: markers of proliferation in the diagnosis of breast cancer. Acta Histochem, 2016, 118(5):544-552. https:// doi.org/10.1016/j.acthis.2016.05.002 PMID: 27246286

[60] Bai X, Yi M, Xia X, Yu S, Zheng X, Wu K. Progression and prognostic value of ECT2 in non-small-cell lung cancer and its correlation with PCNA. Cancer Manag Res, 2018, 10:40394050. https://doi.org/10.2147/CMAR.S170033 PMID: 30319288 PMCID: PMC6167987

[61] Curti V, Di Lorenzo A, Dacrema M, Xiao J, Nabavi SM, Daglia M. In vitro polyphenol effects on apoptosis: an update of literature data. Semin Cancer Biol, 2017, 46:119-131. https://doi.org/10. 1016/j.semcancer.2017.08.005 PMID: 28830771

[62] Manach C, Scalbert A, Morand C, Rémésy C, Jiménez L. Polyphenols: food sources and bioavailability. Am J Clin Nutr, 2004, 79(5):727-747. https://doi.org/10.1093/ajcn/79.5.727 PMID: 15113710

[63] Tresserra-Rimbau A, Lamuela-Raventos RM, Moreno JJ. Polyphenols, food and pharma. Current knowledge and directions for future research. Biochem Pharmacol, 2018 , 156:186-195. https://doi.org/10.1016/j.bcp.2018.07.050 PMID: 30086286

[64] Di Lorenzo C, Colombo F, Biella S, Stockley C, Restani P. Polyphenols and human health: the role of bioavailability. Nutrients, 2021, 13(1):273. https://doi.org/10.3390/nu13010 273 PMID: 33477894 PMCID: PMC7833401

\section{Corresponding author}

Teodora Costea, Associate Professor, Pharm, PhD, Department of Pharmacognosy, Phytochemistry and Phytotherapy, Faculty of Pharmacy, Carol Davila University of Medicine and Pharmacy, 6 Traian Vuia Street, Sector 2, 020956 Bucharest, Romania; Phone +40722-554 665, e-mail: teodora.costea@umfcd.ro 